\title{
ANALYSIS OF CHEMICAL COMPOSITION IN PORK LONGISSIMUS MUSCLE OF LATVIAN BREED PIGS
}

\author{
Liga Paura ${ }^{1,2}$ Lilija Degolaํ, Daina Jonkus ${ }^{1}$ Ilze Gramatina ${ }^{3}$ \\ ${ }^{1}$ Institute of Animal Science, Latvia University of Life Sciences and Technologies, Liela str. 2, Jelgava, LV-3001, \\ Latvia \\ 2 Department of Control Systems, Latvia University of Life Sciences and Technologies, Liela str. 2, Jelgava, LV-3001, \\ Latvia \\ ${ }^{3}$ Department of Food technology, Latvia University of Life Sciences and Technologies, Rigas str. 22, Jelgava, \\ LV-3001, Latvia
}

To link to this article: https://doi.org/10.11118/actaun201967051189

Received: 1. 7. 2019, Accepted: 30. 8. 2019

To cite this article: PAURA LIGA, DEGOLA LILIJA, JONKUS DAINA, GRAMATINA ILZE. 2019. Analysis of Chemical Composition in Pork Longissimus Muscle of Latvian Breed Pigs. Acta Universitatis Agriculturae et Silviculturae Mendelianae Brunensis, 67(5): 1189-1194.

\begin{abstract}
The aim of this study was to investigate the pork chemical composition (protein, intramuscular fat, cholesterol) and fatty acid composition (SFA, PUFA, MUFA) of the longissimus dorsi muscle of purebred Latvian White (Latvian Yorkshire) and crossbred Latvian Yorkshire and Landrace pigs

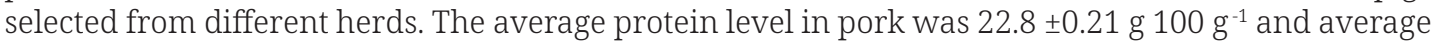
intramuscular fat (IMF) $5.6 \pm 0.62 \%$. It was found that IMF in investigated meat samples was higher than the ideal level. The crossbred pigs produced meat with higher protein level $(p<0.05)$ and with

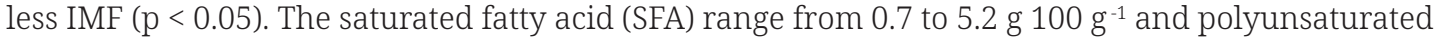

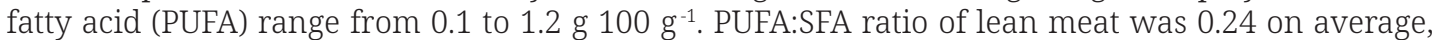
which is less than the recommended minimum and did not exceed the value 0.4 . The crossbred pigs meat contained significantly lower SFA with higher PUFA:SFA ratio $(p<0.05)$ compared to those of purebred pigs. Investigated pork samples contain higher level of omega- 6 (n-6) and a small level of omega-3 (n-3) with evaluated n-6:n-3 ration 4:1 to 11:1. However, in our investigation were samples of pork in which the IMF was in the recommended range 2-3\% and with higher protein and omega-3 level. In general, pork chemical and fatty acid composition depended on pigs genetic.
\end{abstract}

Keywords: pork, pork quality, intramuscular fat, cholesterol, fatty acid composition

\section{INTRODUCTION}

The total meat production in Latvia has been increasing between 2000 and 2017 and ranged from 60,000 tonnes to 87,000 tonnes. The pork production during this period was higher to compare with beef and chicken production and was around half of all produced meat in Latvia. Pork production was more stable in a range from 32,000 tonnes to 41,000 tonnes per year (Fig. 1).

However, the meat production per capita is increasing from $26 \mathrm{~kg}$ in 2000 to $44 \mathrm{~kg}$ in 2016, of which pork production per capita is increasing from $13 \mathrm{~kg}$ to $18 \mathrm{~kg}$. Pork is the most popular meat in Latvia.
Chemical composition varies depending on the pig’s diets (Václavková et al., 2011; Park et al., 2012; Inserra et al., 2015), physiological - sex, age (Lo Fiego et al., 2010) and genetic factors (Cameron and Enser, 1991; Jukna et al., 2007; Jukna et al., 2013; Choil et al., 2016).

Pork muscle tissue in average contains $70 \%$ to $75 \%$ moisture, $18 \%$ to $22 \%$ protein, $2 \%$ to $3 \%$ fat. In Large white (LW), crossbred of Landrace and LW, crossbred of Yorkshire and LW m. longissimus dorsi the content of moisture varied from 72 to $75 \%$, protein from 23 to $24 \%$, and fat from 1.6 to $1.9 \%$ (Jukna et al., 2013). 


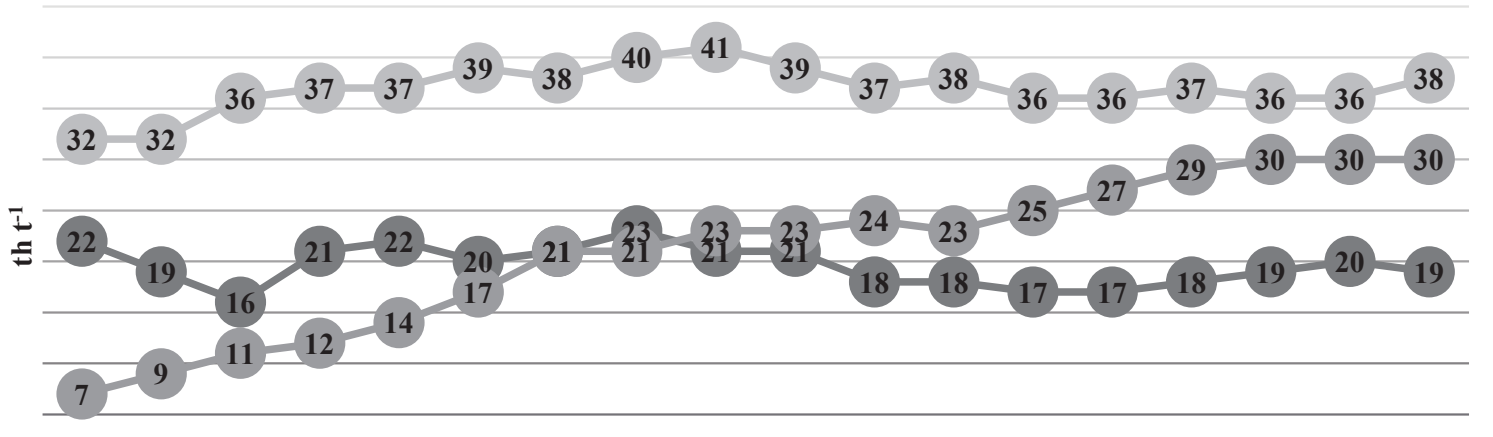

200020012002200320042005200620072008200920102011201220132014201520162017

Year

$\longrightarrow$ Beef and veal $\rightarrow$ Pork $\rightarrow$ Poultry meat

1: Meat production in Latvia 2000-2017 (th $\left.t^{-1}\right)$

Source: Central Statistical Bureau of Latvia, http://www.csb.gov.lv/en

Pork is not only the source of the protein and minerals but as well provide the fatty acids for the human diet. Meat contains saturated, monounsaturated and polyunsaturated fatty acids. Polyunsaturated fatty acids (PUFA) are major flavour precursors of the meat (Wood et al., 2004). Moreover, nutritionists recommend for a consumer to increase PUFA and decrease saturated fatty acids (SFA) in the diet. Meat with higher PUFA:SFA ratio and a high proportion of $n-3$ PUFA is beneficial from the nutritional point of view (Wood and Enser, 2017).

The aim of the study is to investigate the pork chemical composition (protein, intramuscular fat, cholesterol) and fatty acid composition (SFA, PUFA, MUFA) of the $m$. longissimus dorsi of Latvian local and commercial pig breeds.

\section{MATERIALS AND METHODS}

During the investigation 30 pork samples of ten purebred Latvian White (Latvian Yorkshire) and twenty crossbred Latvian Yorkshire and Landrace pigs were collected and analysed. The pigs were slaughtered with a live weight $100-120 \mathrm{~kg}$. The average pigs carcass weight was $83.7 \pm 2.22 \mathrm{~kg}$ with average carcass weight income $67.4 \pm 1.06 \%$. After slaughtered, from the right side of the carcasses, $0.5 \mathrm{~kg}$ of the $\mathrm{m}$. longissimus dorsi were obtained between $5^{\text {th }}$ and $10^{\text {th }}$ rib. Each sample was placed in a plastic tube without contact between samples.

The pork technological quality was analysed during the 24 hours post mortem in fresh samples at Latvia University of Life Sciences and Technologies (LLU) laboratory. Crude protein content was determined using the Kjeldahl method (ISO 937:1978), with Kjeltec 2100 (FOSS, Sweden), and a conversion coefficient 6.25 to convert the total nitrogen to crude protein was used (Januškevičiene et al., 2012). Intramuscular fat defined by the ISO 1443:1973 standards. For the fat content determination was used SoxCapTM 2047 in combination with Soxtec extraction equipment (FOSS, Sweden). All analyses were done twice.

The samples used for the analysis of the fatty acids were frozen at $-18{ }^{\circ} \mathrm{C}$ before sending to the laboratory. The Fatty acid composition of samples were analysed in J.S. Hamilton Poland S.A. laboratory ${ }^{1}$ according to methods PN-EN ISO 129661:2015-01 and PN-EN ISO 12966-2:2011². As well in Hamilton laboratory hydroxyproline by PN-ISO 3496:2000, tryptophan by PB-136/HPLC (ed. I of 06.02.2012) and cholesterol by gas chromatography method (PB-75/GC ed. I of 20.01.2009) were analysed.

For the data analysis purebred and crossbred pigs pork samples were divided into three groups: $1^{\text {st }}$ group Latvian White (Latvian Yorkshire) pigs pork samples; $2^{\text {nd }}$ group Latvian Yorkshire and Landrace (50\%:50\%) and $3^{\text {rd }}$ group Latvian Yorkshire and Landrace (25\%:75\%) crossbred pigs pork samples. 10 samples were included into each group.

Data analysis was processed using $\mathrm{R}$ software ( $\mathrm{R}$ Core Team, 2017). The investigated groups influence to the pork chemical and fatty acid composition of the intramuscular fat of $m$. longissimus dorsi was analysed by one way ANOVA on the significant levels $p<0.05,0.01$ and 0.001 . The Bonferroni test was applied to compare

1 www.hamilton.com.pl

2 https://hamilton.com.pl/wp-content/uploads/2017/12/FOOD-analytical-services.pdf 
the differences in chemical composition traits among the different genotypes. Data in the tables below is reported as means \pm Standard Error of means. The differences between means were tested at significant level $\mathrm{p}<0.05$.

\section{RESULTS AND DISCUSSION}

\section{Analysis of the Chemical Composition of $M$. Longissimus Dorsi}

The results show that the average protein level

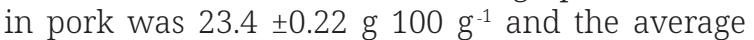
intramuscular fat (IMF) $4.6 \pm 0.51 \%$. IMF is higher than the ideal level, which is considered as 2-3\% and fresh meat with IMF over 3.5\% can be rejected by consumer (Fernandez et al., 1999), because is associated with the sensory evaluation of the meat.

The average values of the chemical composition of the $m$. longissimus dorsi of investigated groups are given in Tab. I. There are significant differences between the investigated groups in protein and IMF level. The $3^{\text {rd }}$ group compare to the group 1 and the group 2 produced meat with higher protein level

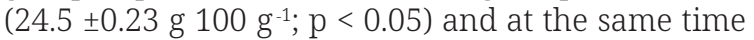
meat was with less IMF $(2.7 \pm 0.47 \%, \mathrm{p}<0.05)$. The IMF level in the $3^{\text {rd }}$ group is in recommended range (2-3\%). A negative correlation was found between pork protein content and $\operatorname{IMF}\left(\mathrm{r}_{\mathrm{xy}}=-0.53379\right.$; $\mathrm{p}<0.05$ ). In several investigations (Daszkiewicz et al., 2005; Zymantiene et al., 2008) were reported the samples with higher protein are characterized with lower fat content.

Significant differences between the groups were observed in amino acids of the proteins hydroxyproline (Hyd) $(\mathrm{p}<0.05)$ and tryptophan (Trp) (p < 0.001), and in hydroxyproline:tryptophan (Hyd:Trp) ratio $(p<0.001)$. The $3^{\text {rd }}$ group meat

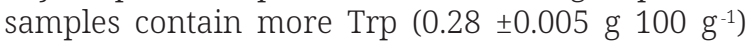
with higher Trp:Hyd ratio (5.76 \pm 0.63 ). The higher Trp:Hyd ratio determined biological value of the pork protein. However, proline and hydroxyproline are the major amino acids in the collagen proteins and are the major extracellular components in connective tissues which are very important for pig growing (Guoyao et al., 2011). The Tryptophan is only in muscle tissue. Our results of Trp:Hyd ratio compared with other research (6.82 \pm 0.33$)$ (Zymantiene et al., 2008), are lower.

The differences in average cholesterol content between investigated groups was not significant, at the same time there was a tendency the cholesterol level was higher in the meat of the $1^{\text {st }}$ group compare to the $2^{\text {nd }}$ and the $3^{\text {rd }}$ groups. The IMF and cholesterol parameters were higher in the $1^{\text {st }}$ group meat samples. However, a higher IMF content in samples related with higher cholesterol level $\left(r_{x y}=0.23\right)$. According to the Jacyno et al. (2006) investigation, the meat of the fatteners (lean meat content $54.7-60 \%)$ contained by $9.5 \%$ less cholesterol.

The LW (LY) local breed pork samples were with higher IMF and lower protein content compare to the crossbred pigs. The intramuscular fat content has a positive effect on meat juiciness, hardness and flavour (Alonso et al., 2009). Our results are the same as in the other research where the lowest amount of intramuscular fat in crossbred LWx L pig meat was found; it was by 0.17 percent lower than in LWXY and even by 0.28 percent lower than in LW pig breed meat. The intramuscular fat is the most variable component of the meat (Jukna et al., 2007). The variation coefficients of fat were several times higher as those are in others meat ingredients; the highest variability of the traits was in LWxL crossbred and the lowest in LW pigs' meat (Jukna et al., 2013).

\section{Analysis of the Fatty Acid Composition of $M$. Longissimus Dorsi}

In studied samples, the saturated fatty acids (SFA)

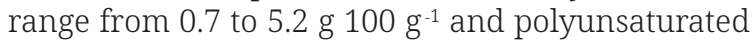

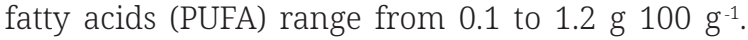
PUFA:SFA ratio of lean meat was 0.24 in average,

I: Chemical composition and amino acids of $m$. longissimus dorsi of investigated groups

\begin{tabular}{lcccc}
\hline \multicolumn{1}{c}{ Traits } & $\begin{array}{c}\text { LW (LY) } \\
\text { Group 1 }\end{array}$ & $\begin{array}{c}\text { LY x L } \\
\text { (50\%:50\%) } \\
\text { Group 2 }\end{array}$ & $\begin{array}{c}\text { LY x L } \\
(25 \%: 75 \%) \\
\text { Group 3 }\end{array}$ & p-value \\
\hline Protein, g 100 g ${ }^{-1}$ & $22.4 \pm 0.31^{\mathrm{a}}$ & $23.2 \pm 0.25^{\mathrm{a}}$ & $24.5 \pm 0.23^{\mathrm{b}}$ & $* * *$ \\
\hline Hydroxyproline, \% & $0.08 \pm 0.01$ & $0.08 \pm 0.01^{\mathrm{a}}$ & $0.05 \pm 0.01^{\mathrm{b}}$ & $*$ \\
Intramuscular fat, \% & $5.6 \pm 1.12^{\mathrm{a}}$ & $5.6 \pm 0.61^{\mathrm{a}}$ & $2.7 \pm 0.47^{\mathrm{b}}$ & $*$ \\
Tryptophan, g 100 g ${ }^{-1}$ & $0.24 \pm 0.01$ & $0.26 \pm 0.00$ & $0.28 \pm 0.01$ & $* * *$ \\
Hydroxyproline: Tryptophan ratio & $0.33 \pm 0.04^{\mathrm{a}}$ & $0.32 \pm 0.02^{\mathrm{b}}$ & $0.20 \pm 0.03^{\mathrm{c}}$ & $* * *$ \\
Tryptophan: Hydroxyproline ratio & $3.31 \pm 0.38^{\mathrm{a}}$ & $3.30 \pm 0.24^{\mathrm{a}}$ & $5.76 \pm 0.63^{\mathrm{b}}$ & $*$ \\
Cholesterol, mg 100 g ${ }^{-1}$ & $62.4 \pm 2.92$ & $57.3 \pm 3.05$ & $58.1 \pm 4.28$ & NS \\
\hline
\end{tabular}

LW (LY) - Latvian White (Latvian Yorkshire), LY x L - Latvian Yorkshire x Landrace; NS - not significant ( $>$ > 0.05); Statistically significant $* p \leq 0.05,{ }^{* *} p \leq 0.01,{ }^{* * *} p \leq 0.001 ; a, b-$ means differences within a row statistically significant $(\mathrm{p} \leq 0.05)$ 
II: Fatty acid composition of the intramuscular fat of $m$. longissimus dorsi of investigated groups

\begin{tabular}{|c|c|c|c|c|}
\hline Traits & $\begin{array}{l}\text { LW (LY) } \\
\text { Group } 1\end{array}$ & $\begin{array}{c}\text { LY X L } \\
\text { (50\%:50\%) } \\
\text { Group 2 }\end{array}$ & $\begin{array}{c}\text { LY x L } \\
\text { (25\%:75\%) } \\
\text { Group 3 }\end{array}$ & $\mathrm{p}$-value \\
\hline SFA g $100 \mathrm{~g}^{-1}$ & $2.26 \pm 0.45^{\mathrm{a}}$ & $2.13 \pm 0.22$ & $1.07 \pm 0.16^{\mathrm{b}}$ & $*$ \\
\hline MUFA g $100 \mathrm{~g}^{-1}$ & $2.82 \pm 0.57^{\mathrm{a}}$ & $2.84 \pm 0.32^{\mathrm{a}}$ & $1.23 \pm 0.21^{b}$ & $*$ \\
\hline PUFA g $100 \mathrm{~g}^{-1}$ & $0.46 \pm 0.09$ & $0.59 \pm 0.07$ & $0.34 \pm 0.09$ & NS \\
\hline Omega-3 (n-3) g $100 \mathrm{~g}^{-1}$ & $<0.1$ & $0.11 \pm 0.01$ & $<0.1$ & - \\
\hline Omega-6 (n-6) g $100 \mathrm{~g}^{-1}$ & $0.44 \pm 0.09$ & $0.49 \pm 0.06$ & $0.31 \pm 0.08$ & NS \\
\hline Omega (n-9) g $100 \mathrm{~g}^{-1}$ & $2.41 \pm 0.49^{a}$ & $2.50 \pm 0.29^{\mathrm{a}}$ & $1.08 \pm 0.19^{b}$ & $*$ \\
\hline PUFA:MUFA ratio & $0.17 \pm 0.02^{\mathrm{a}}$ & $0.21 \pm 0.01$ & $0.25 \pm 0.03^{b}$ & $*$ \\
\hline PUFA:SFA ratio & $0.21 \pm 0.02$ & $0.28 \pm 0.01$ & $0.28 \pm 0.04$ & NS \\
\hline MUFA:SFA ratio & $1.22 \pm 0.03$ & $1.32 \pm 0.03^{\mathrm{a}}$ & $1.12 \pm 0.03^{b}$ & $* * *$ \\
\hline
\end{tabular}

LW (LY) - Latvian White (Latvian Yorkshire), LY x L - Latvian Yorkshire x Landrace; NS - not significant ( $>>0.05)$; Statistically significant $* p \leq 0.05,{ }^{* *} p \leq 0.01,{ }^{* * *} p \leq 0.001 ;$ a,b - means differences within a row statistically significant ( $\mathrm{p} \leq$ 0.05); SFA - Saturated fatty acids, MUFA - Monounsaturated fatty acids, PUFA - Polyunsaturated fatty acids

which is less than recommended minimum 0.4 by World Health organisation (WHO) and in other authors' investigations. IMF has a lower polyunsaturated fatty acid (PUFA) content and a higher percentage of SFA, while monounsaturated fatty acid content (MUFA) is similar in IMF and back fat (Pena et al., 2016).

The average values of the fatty acid composition of the intramuscular fat of the $m$. longissimus dorsi of investigated groups are given in Tab. II. The analysis shows that there was a significantly lower SFA and MUFA level $(p \leq 0.05)$ in pork of the $3^{\text {rd }}$ group, than it was in the $1^{\text {st }}$ and the $2^{\text {nd }}$ groups. There was not significant differences in PUFA level between investigated groups due to high variability within the groups. The SFA and MUFA level depends on the genetic, the crossbred pigs contained significantly lower SFA with higher PUFA:SFA ratio compared to those of purebred LW (LY) local pigs.

Dietetic value of meat depend on cholesterol and fatty acids level and as indicators of the healthfulness of fatty acid profiles are used PUFA:SFA and omega-6:omega-3 (n-6:n-3) ratios (Dugan, 2015). The average PUFA:SFA ratio of the lean meat was higher in the $2^{\text {nd }}$ and $3^{\text {rd }}(0.28)$ groups compare to the $1^{\text {st }}$ group (0.21). In all groups PUFA:SFA ratio was not reached the recommended minimum 0.4. In investigated samples the palmitic acid (C16:0) was the main component of SFA, oleic acid (C18:1cis-9) the main component of monounsaturated fatty acid (MUFA), and linoleic acid (C18:2 n-6) the main component of PUFA.

The pork contained higher level of omega- 6 $(n-6)$ and small level of omega-3 (n-3) (Tab. II) with evaluated n-6:n-3 ration from $4: 1$ to $11: 1$, while nutritionist recommended a diet with $4: 1$ $n-6: n-3$ ratio and diet with high level of omega-3 (Simopoulos, 2008).

In Lim et al. (2013) investigation in Yorkshire and Landrace crossbred pork samples PUFA:SFA ratio was in average 0.35 and an n-6:n-3 ratio 9.75:1. Kasprzyk et al. (2015) have reported in Polish Landrace longissimus tissue PUFA:SFA ratio of 0.24 and an n-6:n-3 ratio of 15.61:1. Choi et al. (2016) investigated fatty acid compassion in longissimus muscles of Duroc, Landrace, Yorkshire pigs and crossbred (DLY) pigs and found the crossbred pigs contained significantly higher poly-, n3- and n6- unsaturated fatty acids compared to those of purebred pigs, including Duroc, Landrace, and Yorkshire pigs.

In our investigation, the fatty acid composition of crossbred pigs were lower with higher PUFA:SFA ratio compared to those of purebred pigs.

\section{CONCLUSION}

The study showed the chemical composition, fatty acid composition of $m$. longissimus dorsi depended on pigs genetic. Generally, the LYxLL crossbred pigs pork samples was with significantly higher protein content and lower IMF compere to the purebred LW (LY) breed. The fatty acid composition of crossbred LYxLL pigs was lower with higher PUFA:SFA ratio compared to those of purebred LW (LY) breed pigs. The IMF in the LYxLL crossbred pigs pork samples were in the recommended range (2-3\%). PUFA:SFA ratio of pork was 0.24 in average and in investigated groups PUFA:SFA ratio did not reach the recommended minimum 0.4. However, there were pork samples in which the IMF was in range $2-3 \%$ and with higher level of omega-3. 
Acknowledgements

Investigation supported by VPP 2014-2017 AgroBioRes Project No. 3 LIVESTOCK.

\section{REFERENCES}

ALONSO, V., MAR CAMPO, M., ESPAÑOL, S., RONCALÉS, P. and BELTRÁN, J. A. 2009. Effect of crossbreeding and gender on meat quality and fatty acid composition in pork. Meat Sci., 81(1): 209-217.

CAMERON, N. D. and ENSER, M. B. 1991. Fatty acid composition of lipid in Longissimus dorsi muscle of Duroc and British Landrace pigs and its relationship with eating quality. Meat Sci., 29(4): 295-307.

CHOI, Y. S., LEE, J. K., JUNG, J. T., JUNG, Y. C., JUNG, J. H., JUNG, M. O., CHOI, Y. I., JIN, S. K. and CHOI, J. S. 2016. Comparison of meat quality and fatty acid composition of Longissimus Muscles from purebred pigs and three-way crossbred LYD pigs. Korean J. Food Sci. Anim. Resour., 36(5): 689-696.

DASZKIEWICZ, T., BAK, T. and DENABURSKI, J. 2005. Quality of pork with a different intramuscular fat (IMF) content. Pol. J. Food Nutr. Sci., 14(1): 31-36.

DUGAN, M. E., VAHMANI, P., TURNER, T. D., MAPIYE, C., JUÁREZ, M., PRIETO, N. and AALHUS, J. L. 2015. Pork as a source of omega-3 (n-3) fatty acids. J. Clin. Med., 4(12): 1999-2011.

FERNANDEZ, X., MONIN, G., TALMANT, A., MOUROT, J. and LEBRET, B. 1999. Influence of intramuscular fat content on the quality of pig meat -2 . Consumer acceptability of $\mathrm{m}$. longissimus lumborum. Meat Sci., 53(1): 67-72.

INSERRA, L., LUCIANO, G., BELLA, M., SCERRA, M., CILIONE, C., BASILE, P., LANZA, M. and PRIOLO, A. 2015. Effect of including carob pulp in the diet of fattening pigs on the fatty acid composition and oxidative stability of pork. Meat Sci., 100: 256-261.

JACYNO, E., PIETRUSZKA, A. and KOŁODZIEJ, A. 2006. Influence of pig meatiness on pork meat quality. Pol. J. Food Nutr. Sci., 56(2): 137-140.

JANUŠKEVIČIENE, G., ZABORSKIENE, G. and KBAŠINSKIENE, A. 2012. Evalution of meat physical, chemical and technological quality. Kaunas: Lietuvos Sveikatos mokslu universitetas.

JUKNA, V., JUKNA, Č. and SAIKEVICIUS, K. 2007. Influence of imported pigs breeds to Lithuanian white pigs meat production and quality. Biotechnology in Animal Husbandry, 23(5-6-1): 67-75.

JUKNA, V., VALAITIENĖ, V., MEŠKINYTÉ-KAUŠILIENE, E. and JANKAUSKAS, A. 2013. Comparative evaluation of large white pigs and their crossbreeds meat nutritional value and mineral content. Veterinarija ir zootechnika, 62(84): 44-49.

KASPRZYK, A., TYRA, M. and BABICZ, M. 2015. Fatty acid profile of pork from a local and a commercial breed. Arch. Anim. Breed., 58: 379-385.

LIM, D. G., KIM, K. T., LEE, K. H., SEO, K. S. and NAM, K. C. 2013. Physicochemical traits, fatty acid and free amino acid compositions of two-way crossbred pork. Korean J. Food Sci. An., 33(2): 189-197.

LO FIEGO, D. P., MACCHIONI, P., MINELLI, G. and SANTORO, P. 2010. Lipid composition of covering and intramuscular fat in pigs at different slaughter age. Ital J of Anim Sci., 9(2): 200-205.

PARK, J. C., KIM, S. C., LEE, S. D., JANG, H. C., KIM, N. K., LEE, S. H., JUNG, H. J., KIM, I. C., SEONG, H. H. and CHOI, B. H. 2012. Effects of dietary fat types on growth performance, pork quality, and gene expression in growing-finishing pigs. Asian-Australas J Anim Sci., 25(12): 1759-1767.

PENA, R. N., ROS-FREIXEDES, R., TOR, M. and ESTANY, J. 2016. Genetic marker discovery in complex traits: a field example on fat content and composition in pigs. Int. J. Mol. Sci., 17(12): 1-17.

R CORE TEAM. 2017. R: A language and environment for statistical computing. $R$ Foundation for Statistical Computing [Online]. Vienna, Austria. Avaible at: https://www.R-project.org/ [Acessed: 2019, September 10].

SIMOPOULOS, A. P. 2008. The omega-6/omega-3 fatty acid ratio, genetic variation, and cardiovascular disease. Asia Pac. J. Clin. Nutr., 17(1): 131-134.

VÁCLAVKOVÁ, E., DANĚK, P. and ROZKOT, M. 2011. Effect of sunflower in pig diet on fatty acid content in muscle and fat tissue of fattening pigs. Research in pig breeding, 5: 44-47.

WOOD, J. D. and ENSER, M. 2017. Manipulating the Fatty Acid Composition of Meat to Improve Nutritional Value and Meat Quality.In: New Aspects of Meat Quality. From Genes to Ethics. Woodhead Publishing Series in Food Science, Technology and Nutrition, pp. 501-535.

WOOD, J. D., RICHARDSON, R. I., NUTE, G. R., FISHER, A. V., CAMPO, M. M., KASAPIDOU, E., SHEARD, P. R. and ENSER, M. 2004. Effect of fatty acids on meat quality: a review. Meat Sci., 66: 21-32.

WU, G., BAZER, F. W., BURGHARDT, R. C., JOHNSON, G. A., KIM, S. W., KNABE, D. A., LI, P., LI, X., MCKNIGHT, J. R., SATTERFIELD, M. C. and SPENCER, T. E. 2011. Proline and hydroxyproline metabolism: implications for animal and human nutrition. Amino acids, 40(4): 1053-1063.

ZYMANTIENE, J., JUKNA, V., JUKNA, C., ZELVYTE, R. and OBERAUSKAS, V. 2008. Comparison of meat quality characteristics between commercial pigs and snails. Pol. J. Food Nutr. Sci., 58(1): 23-26. 
Contact information

Liga Paura: liga.paura@llu.lv

Lilija Degola: lilija.degola@llu.lv

Daina Jonkus: daina.jonkus@llu.lv 